\title{
Benefits of Family Meals ${ }^{1}$
}

\author{
Varnessa McCray, Victor W. Harris, and Martie Gillen²
}

\section{Introduction}

When was the last time you and your family sat down to a good dinner? Recently there has been a shift in society's view of eating family meals together (Condrasky, 2006; Hamilton \& Wilson, 2009). Families today have busy schedules. Kids are involved in extracurricular activities, and many mothers are more active in the workplace. Although most families would say that family meals are valuable, they often allow other things to become a priority, devaluing the act of eating family meals together. Making time for family meals is beneficial to the entire family.

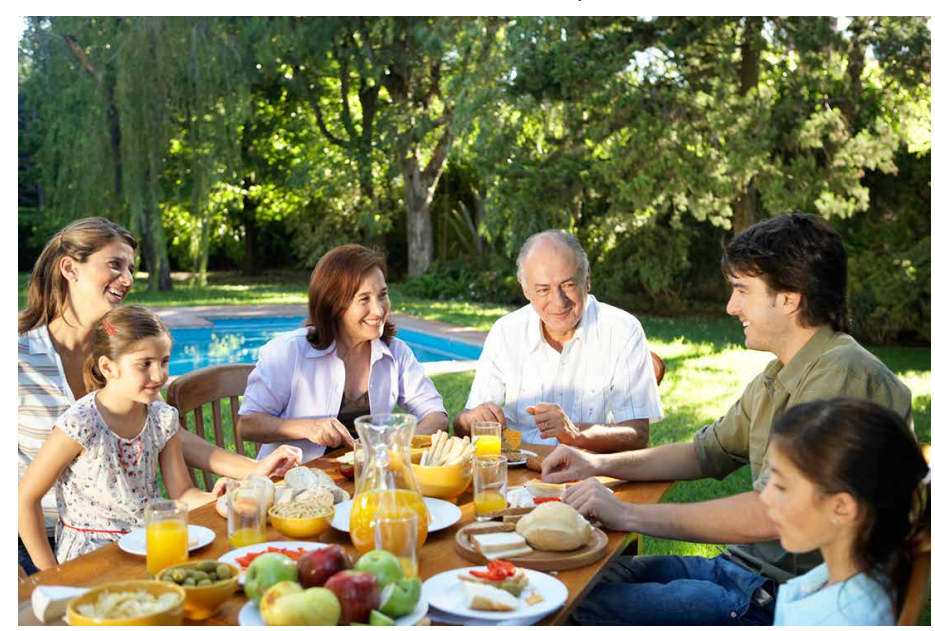

Figure 1. Busy schedules may keep many families from eating regular meals together, but they will benefit from coming together and sharing meals regularly.

Credits: Maria Teijeiro
One way to make sure your family sits down for family meals is to ask your children to help with dinner preparation and make it a fun experience. Some fun programs you can explore are Cooking Up Fun (http://www. cookingupfun.cornell.edu/), Cook It Up, and Cooking with Kids (http://cookingwithkids.net/). All of these can give you some good ideas about how to bond with your children as you prepare family meals. These programs highlight the importance of family meals and the benefits of creating the meal as a family (Thonney \& Bisogni, 2006; Thomas \& Irwin, 2011; Walters \& Stacey, 2009; McIntosh et al., 2010).

\section{Helpful Information}

\section{Why Are Family Meals Important?}

Over the past 30 years obesity among children has increased. Many schools and community programs are encouraging healthy eating choices and habits among youth. One way to help youth make healthy food choices is by creating healthy eating choices and habits at home, starting with family meals. When parents value family dinners, children are likely to view family dinners as important. Family meals can provide important examples to show children what foods are good to eat and how much of the good foods they should eat (Lanigan \& Power, 2008).

\section{BENEFITS OF FAMILY MEALS FOR YOUTH}

Eating family meals together benefits children in several ways.

1. This document is FCS2324, one of a series of the Department of Family, Youth and Community Sciences, Florida Cooperative Extension Service, Institute of Food and Agricultural Sciences, University of Florida. Original publication date April 2013. Visit the EDIS website at http://edis.ifas.ufl.edu.

2. Varnessa McCray, graduate student, Department of Family, Youth and Community Sciences; Victor W. Harris, assistant professor and Extension specialist, Department of Family, Youth and Community Sciences; and Martie Gillen, assistant professor, Department of Family, Youth and Community Sciences; Florida Cooperative Extension Service, Institute of Food and Agricultural Sciences, University of Florida, Gainesville, FL 32611. 


\section{Educational Benefits}

- Increased focus on homework and reading for pleasure (Eisenberg, Olson, Neumark-Sztainer, Story, \& Bearinger, 2004)

- Improved school performance (Hamilton \& Wilson, 2009)

- Greater development of language skills (Snow \& Beals, 2006)

- Increased and more sophisticated level of vocabulary (Snow \& Beals, 2006)

\section{Health Benefits}

- Improved development of healthy eating patterns (Hamilton \& Wilson, 2009)

- Higher intake of several essential nutrients (Croll, Hannan, Neumark-Sztainer, Perry, \& Story, 2003)

- Decreased likelihood of having eating disorders (Ackard \& Neumark-Sztainer, 2001)

- Decreased likelihood of being overweight (Fulkerson, Kubik, Story, Lytle, \& Arcan, 2009)

- Less likely to develop depressive symptoms (Fulkerson et al., 2009)

\section{Social and Behavioral Benefits}

- Less likely to be involved with cigarette, alcohol, and marijuana use (Eisenberg et al., 2004)

- Increased sense of family connectedness, communication, and functioning (Hamilton \& Wilson, 2009)

- Increased likelihood of resisting negative peer pressure (Fulkerson et al., 2006)

- More likely to experience positive identity assets (Fulkerson et al., 2006)

- Less likely to attempt suicide (Fulkerson et al., 2006)

- Less likely to engage in sexual intercourse (Fulkerson et al., 2006)

\section{OVERALL BENEFITS FOR THE FAMILY}

- Regular and consistent family time

- Reduction of anxiety and depression in children
- Increased feeling of togetherness, coherence, and solidarity

- Increased emotional and social bonding

- Shared nutrition

- Relaxing, talking, and laughing as a family unit

\section{Things You Can Use}

Each family can make meals a time of unique family bonding. A few common tips families can use to help each other enjoy family meals and create an atmosphere of warmth, unity, and respect are listed below.

\section{Show interest in your family members by asking about their day.}

Here is an example of how the beginning of this conversation may look:

Father: "Son, tell me something fun you did at school today."

Son: "Me and my friends built a castle at recess."

Mother: "That does sound like fun. Was it a big castle? Did you guys put guards and knights in front to protect the people who live in it?"

These kinds of conversations validate a child and show that they are loved and cared for.

\section{Compliment each other and provide positive feedback, encouragement, and support when necessary.}

This is important because everyone knows it feels good to have someone encourage us and notice our accomplishments. Whether congratulating a spouse on receiving a promotion, encouraging a daughter to apologize to her best friend because of an argument, or giving feedback to a son about his decision to play soccer, family meals provide a unique context in which all kinds of conversations can take place.

\section{Turn off (or silence) television, cell phones, laptops, radios, music players, and other electronic devices.}

This is important because it helps get rid of any distractions and disruptions that can interfere with spending 
true quality (and quantity) time with family members (Hunt, Fazio, MacKenzie, \& Moloney, 2011). As a result, everyone can focus on each other and strengthening family relationships.

\section{Do not interrupt or talk over one another.}

This is important because talking over someone else can be seen as rude and insensitive. Also, not interrupting or talking over someone shows respect to family members and lets them know that others are paying attention to what they are saying.

\section{Plan and prepare meals together.}

This is important because everyone can help decide what meal will be prepared. This process can build decisionmaking and negotiation skills among family members. The skills of providing clear feedback and expectations about what kinds of family meals everyone likes and dislikes can also be developed.

There are many barriers that may prevent families from having family meals. Creating meal plans and allowing everyone to play a role can minimize these barriers (Abbot \& Byrd-Bredbenner, 2010). Table 1 provides a way to

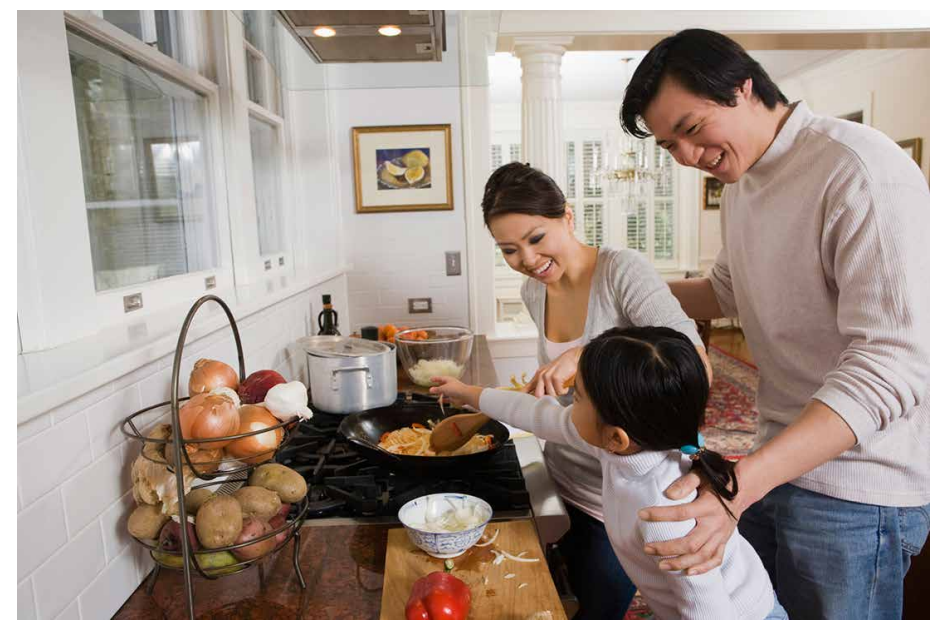

Figure 2. Having your children help with meal planning and preparation can be a fun bonding activity.

Credits: Jupiterimages

plan meals while Table 2 provides a schedule for meal preparation, including cooking, table setting, and cleanup. Table 3 provides a way to track current family meals and to schedule future family meals.

\section{Conclusion}

Eating family meals together typically results in positive benefits for family members. Benefits can include increases in educational, health, social, and behavioral skills. In addition, participating in family meals can increase positive family interactions and overall family well-being. Accessing programs designed to focus on mealtime and family and youth development can be critical to introducing families to the benefits of family meals.

\section{References}

Abbot, J.M., \& Byrd-Bredbenner, C. (2010). A tool for facilitating meal planning. Journal of Nutrition Education and Behavior 42(1), 66-68.

Ackard, D. M., \& Neumark-Sztainer, D. (2001). Family mealtime while growing up: Associations with symptoms of bulimia nervosa. Eating Disorders 9(3), 239-249.

Condrasky, M. (2006). Cooking with a chef. Journal of Extension, 44(4), Retrieved from http://www.joe.org/ joe/2006august/a5.php

Croll, J., Hannan, P.J., Neumark-Sztainer, D., Perry, C., \& Story, M. (2003). Family meal patterns: Association with sociodemographic characteristic and improved dietary intake among adolescents. Journal of American Dietetic Association 103(3), 317-322.

Eisenberg, M. E., Olson, R. E., Neumark-Sztainer, D., Story, M., \& Bearinger, L.H. (2004). Correlations between family meals and psychosocial well-being among adolescents. Archives of Pediatrics \& Adolescent Medicine 158(8), 792-796.

Fulkerson, J. A., Kubik, M. Y., Story, M., Lytle, L., \& Arcan, C. (2009). Are there nutritional and other benefits associated with family meals among at-risk youth? Journal of Adolescent Health 45(4), 389-395.

Fulkerson, J. A., Story, M., Mellin, A., Leffert, N., NeumarkSztainer, D., \& French, S. A. (2006). Family dinner meal frequency and adolescent development: Relationships with developmental assets and high-risk behaviors. Journal of Adolescent Health 39(3), 337-345.

Hamilton, S. K. \& Wilson, J. H. (2009). Family mealtimes: Worth the effort? Infant, Child, \& Adolescent Nutrition 1(6), 346-350.

Hunt, G., Fazio, A. MacKenzie, K., \& Moloney, M. (2011). Food in the family: Bringing young people back in. Appetite 56(2), 394-402. 
Lanigan, J., \& Power, T. G. (2008). Obesity prevention and health promotion: How family life educators view their role. Journal of Extension 46(6). Retrieved from http://www.joe. org/joe/2008december/a5.php

McIntosh, W. A., Kubena, K. S., Tolle, G., Dean, W. R., Jan, J., \& Anding, J. (2010). Mothers and meals: The effects of mothers' meal planning and shopping motivations on children's participation in family meals. Appetite 55(3), 623-628.

Snow, C. E., \& Beals, D. E. (2006). Mealtime talk that supports literacy development. New Directions for Child and Adolescent Development 2006 (111), 51-66.

Thomas, H.M.C., \& Irwin, J. D. (2011). Cook it up! A commucooking program for at risk youth: Overview of a food literacy intervention. BMC Research Notes 4(495), 1-7.

Thonney, P. F., \& Bisogni, C. A. (2006). Cooking up fun! A youth development strategy that promotes independent food skills. Journal of Nutrition Education and Behavior 38, 321-323.

Walters, L. M., \& Stacey, J. E. (2009). Focus on food: Development of the cooking with kids experiential nutrition education curriculum. Journal of Nutrition Education and Behavior 41(5), 371-373. 
Table 1. Meal Planning for Week:

Directions: List the specific meal that your family will eat each day for the days and meals you eat together.

\begin{tabular}{|l|l|l|l|l|l|l|l|}
\hline & Sunday & Monday & Tuesday & Wednesday & Thursday & Friday & Saturday \\
\hline Breakfast & & & & & & \\
\hline Lunch & & & & & & \\
\hline Dinner & & & & & \\
& & & & & & \\
& & & & & \\
\end{tabular}

Table 2. Family Meals Preparation Schedule for Week:

Directions: List the family member(s) in charge of assisting with each task for that day.

\begin{tabular}{|l|l|l|l|l|l|l|l|}
\hline & Sunday & Monday & Tuesday & Wednesday & Thursday & Friday & Saturday \\
\hline Cooking & & & & & & \\
\hline Table-Setting & & & & & & \\
\hline Cleaning Up & & & & & \\
& & & & & & \\
& & & & & & \\
\end{tabular}

Table 3. Family Meals Schedule for Week:

Directions: Mark off each day that your family plans to eat a meal together as well as days that you eat an unplanned meal together. Use different colors to mark the planned meals and the unplanned meals.

\begin{tabular}{|l|l|l|l|l|l|l|l|}
\hline & Sunday & Monday & Tuesday & Wednesday & Thursday & Friday & Saturday \\
\hline Breakfast & & & & & & \\
\hline Lunch & & & & & & \\
\hline Dinner & & & & & \\
\end{tabular}

